\title{
Information and Participatory Research and Action: An Alternative to Avoid Domination and Develop Citizenship
}

\author{
Rosemeire B. Tavares ${ }^{1}$ \\ ${ }^{1}$ Faculty of Information Science, University of Brasilia, Brazil \\ Correspondence: Rosemeire B. Tavares, SQS 307, Bloco H, Apartamento 501 - Brasília / Brazil. Postal Code 70.354-080
}

Received: December 8, 2021

Accepted: January 11, 2022

Available online: February 14, 2022

doi:10.11114/ijsss.v10i2.5484

URL: https://doi.org/10.11114/ijsss.v10i2.5484

\begin{abstract}
Objective: The research presents the effectiveness of Participatory Research and Action (PRA) specifically in information science. The main statement that motivated this qualitative study was that there is no citizenship without critical awareness. This research has the objective to demonstrate that collaborative work combined with multidirectional and interactive communication in PRA can develop critical awareness and citizenship.

Methodology: The study is focused on citizens' critical awareness development. It is based on bibliographical research, within critical thinking theoretical perspective, one of the currents contemplated by subjectivism epistemology. The study search mainly two data sources. First, Borges' article, which presents comparative issues related to socialism and capitalism ideologies. Second, Tavares' PhD thesis, in which PRA techniques were tested. Additionally, findings from several researches related with social development, social rights, popular participation, as well as citizen's manipulation and domination were also collected. Data analysis were based on grounded theory principles, particularly the coding process and textual examination.

Findings: Data analysis revealed three great postulations. First, lack of critical awareness and dissemination of fake news has both guided people to be manipulated, oppressed and dominated. Second, it is essential for citizen to be educated critically to deal with information that affects his life. Finally, it is possible to use PRA to develop critical awareness and citizenship. PRA promotes learning, broadens the notion of citizenship, and develops attitudes such as reading, analyzing and criticizing information, which constitutes an essential skill to developing critical awareness.
\end{abstract}

Keywords: informational literacy, collaborative work, Participative Research and Action, citizen, citizenship, manipulation, domination; critical awareness

\section{Citizens and Citizenship in Information Age}

A citizen is a free member of a particular society, integrated into it by adoption or birth. Society, in turn, is characterized by a set of cultural, political and social roots. The movement of citizens in the sociocultural, economic and political conglomerate is what streamlines societies (DEMO, 2002).

Citizenship contemplates the classic civil, political and social rights, granted by the Constitution to individuals. Marshall's work (1964) reveals that civil rights is related to the birth and recognition of rights within the citizen's society. It comprises, for example, civil record, habeas corpus, the presumption of innocence and the right to trial in legal court with jurors composed by their peers. Political rights are related to the constituted power regime and involve the right to vote, to become a candidate in electoral processes, and participate in public assemblies. Because both civil and political rights are given by law, certificates Constitution, they are easily guaranteed to all members of society, in most nations around the world.

However, social rights are more difficult to consolidate in order to be equally guaranteed to all citizens. They address, for example, rights to employment, housing, health care, quality education, and other social benefits, necessary to citizen's development and, consequently, to strengthening the society itself.

This study points to social rights and social duties for all citizens which may be summarized in two previous standings. First, in individual terms, citizens will have been granted quality education and job. On the other hand, all citizens have to work to achieve own autonomy, emancipation and dignity. Second, in social terms, citizens will have been ensured local community centers equipped with physical, financial and technological structures. In return, all citizens will be 
responsible for solving social problems and managing resources to develop their communities. (TAVARES, 2011).

Demo (2002) observed that the full exercise of social rights and social duties promotes the development of a nation and is given by the restoration of social assets and the redistribution of income and power. Moreover, Calabrese and Burgelman (1999) add that when society privileges economic development without concern for guaranteeing equal social rights for all citizens, it ends up privileging a particular social layer, causing inequality, imbalance, misery and stagnation.

\subsection{Popular Participation and Social Organization of Learning}

The main statement that motivated this study was that there is no citizenship without critical awareness development. Critical awareness can be developed through both embracing of popular participation and creation of social organization that facilitate the learning and empowerment of their members (CHOO, 2006).

According to Cogo and Maia (2006), popular participation methods tend to observe the properties of the argumentative process as publicity, equal rights, lack of coercion and attempt to deceive. Argyris and Schön (1996) asset that social organizations are composed of citizens and its focus is citizen's learning that culminates in community transformation and individual development.

According to Henten (1999), globalization involves a smaller scale of state interventionism, since the economic policy is more subject to international law. Thus, the best way for nations to react to globalization is to strengthen themselves internally, in order to not become that part of the mass $(80 \%)$ exclusively consumer, which revolves around the minority holding the wealth.

Strengthening, however, demand to improve the power of employment, that is, creating skills, knowledge and technology that generates innovation and wealth. Thus, Henten (1999) points out that the State of Social Welfare in the information society is the State that regulates work and education to create the necessary conditions for citizen himself to promote his well-being. "Societies will be more related to work and education issues, as well as how all this should happen" (p.89).

One way for engagement and commitment is through collaborative work, which can be created in two steps. The first one consists of building physical and technological structures where citizens would be together, learning and making decisions about their community development. The second one consists of providing technical and financial resources for citizens to perform their social solutions. These attitudes could contribute to achieving effective solutions and social development since citizens will be committed to the entire process and the consequent results (TAVARES, 2011).

In other words, community's place should be created aimed at learning organization concept. A place where social work can be done, and community members can learn. In these rooms, people will use information to create meaning, build knowledge and make decisions (CHOO, 2006).

\subsection{Participatory Processes, Critical Education and Political Being}

According to Demo (2002, p.130), "human beings thus need to know how to manage inequality, so that societies are at least bearable". Developing the "political being" is fundamental for conquering social rights. It represents the biological capacity to make its own, individual and collective history.

The "political being" manages to interfere in one's destiny through learning and knowledge, which will promote a more egalitarian and polarized coexistence, moving forward to institutional processes that improve the living condition. Critically conscious and well-known citizens present a more reconstructive attitude towards reality, an essential characteristic today in the knowledge society. Although it is impractical to imagine complete autonomy, the citizen can, through knowledge, become more independent and contribute to the development of society in more egalitarian terms (Ibid, 2002).

In a post on BBC News Brazil, Bara (2021) questions why so many young people complete studies without developing a true critical spirit. He asserts that the critical spirit frees us from ignorance. It means that critical awareness frees us from any person, entity or thing that wants to think for us. In this sense, the social environment is full of people and entities attacking the citizens to impose excessive duties and usurp fundamental rights. They do this for the sole purpose of empowering and enriching themselves.

In order to succeed in this task, these people and entities need to dominate and weaken the citizen and do so by attacking their ability to think, reflect and act. They eliminate from education the critical awareness development, so they can control citizens and thus acquire power from the ignorance of their equals. Perhaps this is the answer to Bara's questioning (2021): young people complete studies without developing a true critical spirit because these contents were removed from educational institutions in order to train weak and dependent citizens.

In summary, social rights can be conquered by the citizens themselves, from their transformation into a "political being" 
with a critical capacity to intervene in their destiny through learning and knowledge. The establishment of a strong relationship between man and information causes this transformation. However, this transformation would probably happen if, and only if, communities are transformed into a type of social learning organization, with a physical, financial and technological framework.

Information for citizenship can reduce both inequality of opportunity and social exclusion. Authors such as Calabrese and Burgelman (1999) and Demo (2002) argue that restoring citizens' social rights through access to information and knowledge is necessary. Information has the power to instruct citizens, providing conditions to argue and discuss critically. Additionally, Apple (2008) asserts that critical education plays a key role in citizens' insertion in society. The critical education enables citizens to access and use information, knowledge, and innovation. It is also important to develop moral and ethics skills to form reflexive judgments and balance between personal convictions and impersonal principles of justice (DEMO, 2002).

\subsection{The Cost of Popular Participation}

Anderson, Warburton and Wilson (2005) pointed to the cost of the public participation. Their research's findings are summarized next.

- "Researchers and practitioners for continuing and enhancing public participation. Understanding of the benefits is growing in general terms, although there is significant unwillingness to quantify these benefits and particular reluctance to 'monetarize' the benefits (assign a monetary value to them).

- There is a serious lack of data on the practical costs and benefits of participation, for a range of practical and ethical reasons.

- The lack of understanding of potential costs and benefits makes it difficult to develop a coherent hypothesis about participation overall.

- New analytical frameworks are needed. Participation is a new and cross-cutting approach that is only partly captured by existing academic and professional disciplines. A new theoretical model is needed that goes beyond the disciplines and fields within which participation began.

- Participants' perspectives are critical to defining the costs and benefits of participation. Only by including this perspective alongside that of institutional interests, and considering the wider impacts on local communities and society as a whole, can the true costs and benefits of participation be understood.

- Greater investment in assessing participation processes is required, to build a robust evidence base.

- A simple framework for capturing the actual practical costs and benefits of participation is needed, to complement the wider thinking needed around broad new analytical frameworks. In this way, simple data can begin to be captured and provide benchmarks against which future activity can be tested" (ibid, 2005, p.9).

The authors assert that the absence of robust evidence about the cost of benefits do not impede that the rhetoric on public participation continues to grow. It is the danger of poor participation and on the potentially negative implications for conventional political leadership.

\section{Capitalism, Socialism, State and Democracy}

This section also begin with a statement: either capitalism and socialism adopts actions to weaken citizens, depriving them of their social rights. Both of them intend to control people through the dependent relationship from both workers to State or worker to market. There is not democracy in both, socialism and capitalism.

This statement was examined based on two studies from Borges. The first brought a comparative and complementary position of socialism and capitalism in accordance with Henry's and Hurz's studies (BORGES, 2020-I). The second brought a criticism made to the liberal democracy from Schmitt comparing with Hurz's socialistic studies (BORGES, 2020-II).

According to Borges (2020-I), Henry exposes socialism as an ideology that can be modified in the sense of being decomposed, and then reorganized, for finally being transformed into a source of prosperity and well-being. As a cause of socialism's failure, Henry pointed its effort to organize human beings' activities and lives in a rational and lined way, overlooking their rationality and freedom potential. It is a mistake of conception. The countries in which socialism has been deployed present the same disastrous consequences: economic failure, authoritarian policies, elimination of dissidents, and hunger.

Borges (2020-I) adds, still quoting Henry, that socialism has failed for belittling, diminishing and disrespecting individuals as the main source of wealth generation and pillar of social organization. Devaluing individuals inevitably 
excludes the only true force from social dynamics, which is the worker's strength, as a source for producing wealth. At the political level, this undervaluing results in renouncing human rights, arbitrariness, deportation and death.

Capitalism, in turn, had its deception via appropriation of community assets by large property-owners. Besides, farmers were expropriated from smallholding and moved to cities to be "free" workers in the system guided by market. After being stripped of all means of production, workers start to be measured exclusively as workforce. The genius of the capitalist was to perceive that this force could be bought. That is why all " economy guided by market " is addicted at first.

It is addicted mostly because economic transactions do not occur between two exchange values. They actually occur between an exchange value and a usage value. The exchange value is the worker's EARNINGS, and the usage value is the worker's PRODUCTION. The last (production) does not keep equivalence with the former (earnings), because salary is not connected to production.

In both capitalist and socialist productive processes, there is the exploitation of the labor force. It means that it does not matter what the production value of each worker is. On the contrary, the matter is which worker would be cheaper to produce that particular product. The value of the worker has been defined by the value that is usually necessary for his subsistence, which is always lower than the production value given by the same worker (BORGES, 2020).

Kurz (BORGES, 2020-I) reached conclusions strikingly similar to Michel Henry's. In accordance with Kurz, the end of the Cold War was interpreted as the definitive victory of capitalism, with the illusion that a golden age would arise. The market had opened, in a globalized system. However, the result was a great disappointment. Countries have had wealth losses, besides new social cuts, economic crises, civil wars, and growth of predatory competitiveness.

Kurz pointed to two post-war society systems. The first one adopted a model that is more regulated by the state, and the second one adopted a model that is more regulated by the market. The author added yet that these societies did not have different points, but rather the common points, since they are both linked to goods and services production. Therefore, it does not matter which model each society adopted; they have a common point: to commerce goods and services and exploit the workforce.

In pre-modern societies, goods production was only a marginal issue to ensure the development of societies and citizens. Money played a role as a mediator between different "objects of need". The desire or need was related to having money for acquiring goods. In turn, modern societies have money as a good, so money is no longer a mediator to acquire goods. It becomes an asset by itself.

The relationship is reversed. In pre-modern societies, acquiring objects of need was the final step in the production system, and money was only a mean for acquiring these objects. Nowadays, acquiring objects of need has been a mean for accumulating capital and money. The consequence of this reversal is "having it" by having, and not "having it" because it is a needed. In addition, workers have been reduced to a mere production factor and mere consumers. As a consequence, they receive less for the product they produce and pay more for the same product when they buy it. Thereby, the modern production system has generated an excess of capital for owners.

According to Borges (2020-I), Kurz classifies as naïve the typical conception of Marxist movements, that the origin of all social injustices would reside primarily in the appropriation of the work of others. In opposition, he states that coercion in the capitalist system is not personal, as in a relationship between lord and servant; it is an anonymous system of coercion, which results in domination without a subject (might be socialism, capitalism, the State, the market, among other entities).

Marxists insist on the themes of added value and domination. However, they devote little attention to the systemic aspects of the economy unrelated to human needs. This lack of attention led to a progressive loss of the mobilization power of left-wing movements. It was also due to the growing misstep between their intellectual leaders' discourse and the masses' empirical perceptions about their exploitation processes. It means that leaders promise a better life, but living is more difficult on citizen's perception. They promise a fairer society, but, on citizens' perception, society is increasingly centralized and most citizens are poorer and more exploited. They promise freedom, but, on citizens' perception, oppression has been increased.

Criticism of liberal democracy in Carl Schmitt and Robert Kurz (BORGES, 2020-II) brought a study that aims at comparing the similarities contained in criticism of liberal democracy present in some selected works of Carl Schmitt (1888-1985) and Robert Kurz (1943-2012). Borges pointed numerous similarities between the two authors, which are verified when they attempt to analyze the characteristics of parliamentarian liberalism in twentieth-century democracies.

Schmitt accuses liberalism as hypocritical. It has been used universal principles but only as an excuse to defend particular interest and selfish economic aims. Liberalism is not a State's theory, despite it has not denied the State. 
Actually, liberalism searched the State only to link the political from the ethical and submit both to economic. It means that in liberalism ideology, all entities and person are submitted to the market.

There is a conclusion in these findings at least. It is neither about personal domination (employer $\mathrm{x}$ employee) nor added value (exploitation of work by the employer). Rather, it is an economic system detached from human needs who appropriates domination, added value and other means of production to accumulate wealth, in a system globalized, centralized and detached from necessity. This system can be perpetuated under the aegis of any political ideology or economic regime and certainly generates social injustice and citizen mutilation. Therefore, they cause harmful effects to society and citizenship development.

\section{Brazil and Desiformation}

Brazil is currently experiencing a war between right-wing and left-wing ideologies. What is perceived in this war is the clear interest of leaders to remain in power and exercise dominance over citizens. There is no intention to strengthen and protect citizens; on the contrary, there is a clear intention to deceive citizens with false information in order to use them as manipulated receiver.

In this specific case, both socialism and capitalism have significant advantages and disadvantages regarding social development. The capitalist discourse focuses on attacking socialist disadvantages, and reinforces their own advantages. On the opposite, the socialist discourse attacks capitalism through its disadvantages and reinforces its own advantages. Thus, they have both gained adherents, due to citizens' fear of the disadvantages from the other system. The war between socialism and capitalist maintains dominance over citizens from fake news or half-truths, taking the citizen out of focus, dividing Brazilians into party groups and weakening the nation as a unit of work, strength and development.

There is another dichotomy in productive systems from these two ideologies. On one hand, there are exploited citizens who need to be dominated in order to work more and earn less. For being dominated, there are employees deprived of an education that qualifies them for work, therefore makes them uninformed about their rights and duties. On the other hand, there are employers who are losing productivity and competitiveness because their workers are unmotivated and poorly educated.

An education that develops technological abilities and critical awareness makes staffs much stronger, smarter and hard to control. They stop being productive resources for being a partner. They would probably start debating, claiming, and fighting for the same cause: social rights. They would be probably free to interfere in their own destiny with assertiveness to really achieve autonomy, emancipation and dignity (FREIRE, 2007 and DEMO, 2002).

Nonetheless, everybody gains in this process. Employees get productivity and competitiveness, and thus they will increase their incomes. Employers get empowerment from education to manage their lives and achieve autonomy, emancipation and dignity. Communities will have local problems solved by communities' members. Government and State will be more effective by focusing in nation development.

It is not easy to manage strong, smart and conscious citizens. They are independent, learn by themselves, and are able to share knowledge and responsibility. Owners, in this hypothetical situation, would probably have to share part of their gain, that is, part of the added value. However, owners' wealth would probably enlarge by increasing productivity and the quality of products for sale. Besides, owners would probably have staff much more compromised and enlaced with their work, as well as more productive, creative and efficient. These results surely will increase wealth, but maybe without an exorbitant added value for them.

Disinformation allows leaders practice false discourses. They might present projects which either they do not have any intention to execute or do not bring any benefit for citizen. Leaders only do this because citizens do not know how to charge, claim, or demand positive results from leaders. There are no serious employment policies in Brazil that provide properly work and education for citizens, for example. On the contrary, leaders have promised to end the misery not by work, but by sharing family grant. As a result, government is mutilating citizens, taking their capacity to be autonomous, and so creating a dependent relationship between citizen and their leaders.

Rinaldi (2019) adds that the media is one of the forces behind this problem. The circulation of fake news has become profitable for companies that use this artifice. The capitalist system implements consumption needs linked to pseudo-happiness, but it actually wants only to sell products to increase profits. In turn, the socialist system implements the idea of equality, but it actually divides citizens by groups (gender, class, origin and sex condition, for example), stimulating discords between each other. Therefore, the citizens are alienated and easily influenced by liars that circulate more and more in the media.

Rinaldi (2019) points to two measures to solve this problem. First, fake news has to be treated as a crime, liable to fine and imprisonment, in more serious cases. Second, citizens should be instructed to access information and analyze it critically before using it and disseminating it. Again, citizens need to be educated to access and use information 
consciously and critically.

\section{A Model of Learning Organization for Citizenship}

This research started from the premise that there is no citizenship without critical awareness. It keeps showing a sort of studies evidencing the importance to insert community members into the information and knowledge society. Finally, the study intends to present a modal of learning organization for citizen. This model uses participatory research techniques, which focus on both information literacy and collaborative work. The objective is to demonstrate that participatory research contributes to citizenship development at a time when enables citizens to manage information and solve problems within their community in a collaborative way.

Although the individual development of these skills is possible, according to the social constructivist perspective of learning (MACKERACHER, 2004), informational literacy that leads to community development is different and probably much more effective. Lloyd (2007), for example, reshapes the nature of informational literacy, from the individual sphere to a community sphere as an approach included in the socio-cultural context. Additionally, participatory approaches to problem solving have been identified as effective forms of community members' engagement. Participation leads people to develop sustainable solutions that genuinely express the needs of community members (more than those unsustainable solutions that outside experts impose). By using participatory methods, research will also act as a mechanism that helps develop new insights and capabilities in people. This is one of the characteristics of PRA (CHAMBERS, 2005).

This study suggests a solution for the imbalance between citizens and State or Market. By using PRA, it is possible to develop critical awareness and citizenship. PRA is based on the theoretical perspective of critical thinking. It is more concerned with the development of critical awareness than with the solution of the problem itself.

Tavares (2011) defined a conceptual model of communication of information and citizenship. The model, represented in Figure 1, highlights not only these concepts but also their relationship.

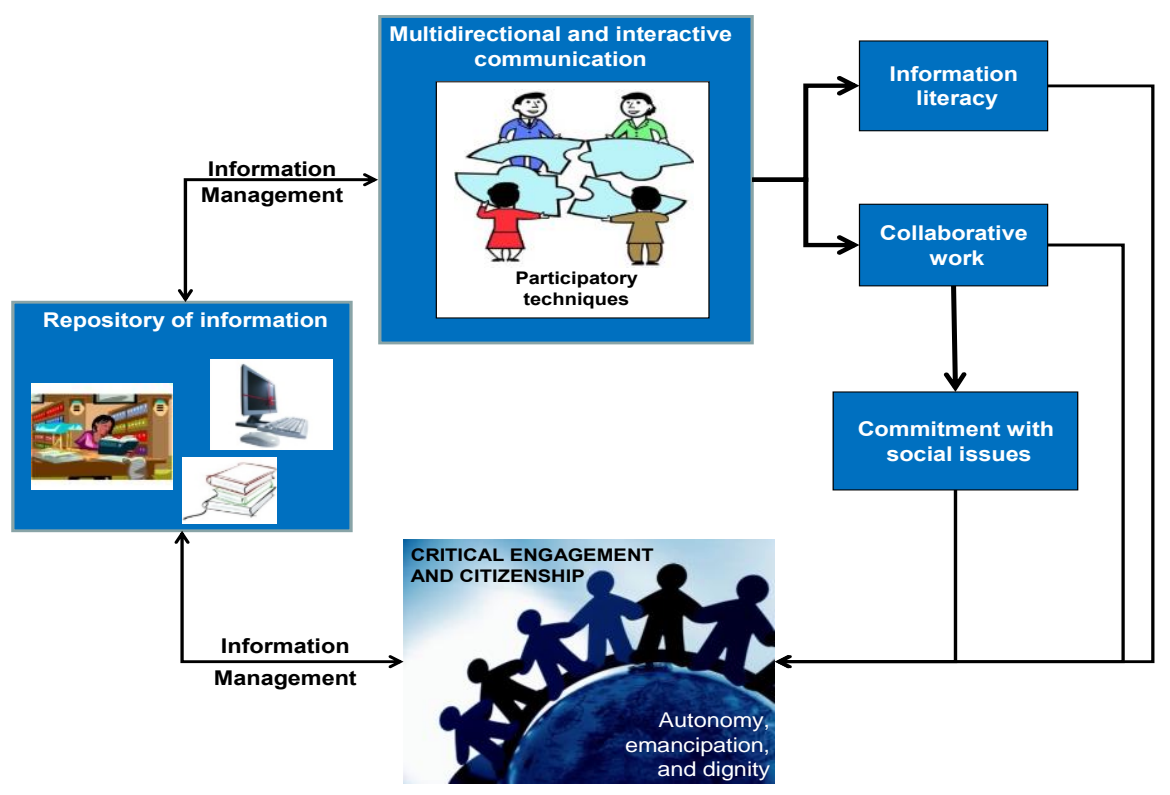

Figure 1. Conceptual Model of Participatory Process

The conceptual model points to the process of effective communication between citizens in order to develop information literacy skills and collaborative work. It is premised that participatory research techniques combined with informational literacy constitute essential to communicate in an interactive and multidirectional way. Allied to this, a channel of communication between the community members contributes to the critical and technical development of the citizens, enabling them to conquer autonomy, emancipation and dignity. Therefore, by encouraging people to discuss and propose solutions to social problems, they experience, in the community where they live, the participatory process contribution to the development of the community through critical awareness of its members, commitment and social responsibility (BROOKFIELD, 1987).

Thus, an ideal model of communication of information for citizens should promote citizens' autonomy as communicators - spreaders and receivers simultaneously - not as mere receivers, in which citizens solve their social problems. This 
process will develop the community through the growth, engagement and commitment of their citizens.

Finally, a model of communication of information for citizens must be transactional. It means that communication is multidirectional, from many to many. Thus, the environment where citizens will communicate, access and use information, and share experience and knowledge, should constitute a learning environment. Skills such as teamwork, talking and listening, respecting differences, analyzing problems, and making decisions are examples of topics to explore in these learning communities. The production system in any society has had an imbalance from dialogue to practice. Political leaders, both socialist and capitalist, have presented themselves as citizen's protector. Both have committed to supply citizens' needs as well as to promote workers' dignity.

The theoretical perspective of critical thinking shares many characteristics with PRA, which provided the methodological structure and influenced the interventions. PRA has been widely applied in developing countries, initially with the name Participatory Rural Appraisal. Chambers (2005) asserts that PRA is "a set of approaches, behaviors and methods to enable people to do their own planning, analysis and evaluations, implement their own actions and act themselves to inspector and control these actions" (translated by the author, ibid, p.3). Using a participatory approach, many topics can be discussed in groups, but the discussion is strongly structured in participatory rules. Thus, the key aspect of PRA is the development of capabilities, i.e., skills and attitudes.

Cohen and Uphoff (1980) advocate that governments need to adopt popular participation as a guideline and basis for development. They argue that participation is a basic necessity, and give some examples: The United Nations Economic and Social Council (UNESCO) has advised countries to include proposals for popular participation in their government programs. Also, the World Employment Conference has an action named "people participation the in decision-making process that affect them discussing their choices and planning" (translated by the author, ibid, p.18). Popular participation in institutions that govern their lives is a basic human right and it is essential to realign political powers in favor of citizens as well as for economic and social development (translated by author, ibid, p.18).

Cornwall (1996) notes that PRA can mobilize the population to support change. In addition, popular participation, as a government policy, promotes efficiency and effectiveness. Popular participation encourages voluntary work, which improves the quality and quantity of public services available to the population without burdening the government's budget.

Through popular participation, citizens become a government knowledgeable partner. As a result, the performance of public administration will be much better and more effective. Additionally, government projects would probably succeed when community members are involved, because there is engagement and commitment, and it is vital to the success of any enterprise (KURFISS, 1997).

Many organizations agree that there is no sustainable development without popular participation. Participation is a centerpiece of development, according to Kumar (2008). PRA carries the idea that participation promotes greater democracy, equality and social justice, in addition to promote citizens' autonomy, emancipation and dignity.

\subsection{Findings from PRA}

Tavares's doctoral thesis (2011) was developed from the use of PRA. It aimed to show that PRA is a proper methodology to develop citizenship. Two concepts were used: informational literacy and collaborative work. Data were gathered in a small community at Candangolândia/Brasília/Brazil. The work was conducted in periodic meetings so that all participants could define a common social problem and then analyze, discuss, access and use information, negotiate and seek consensus to finally point out solutions. All meetings began and ended with an evaluation of the participatory process itself.

Regarding the evaluation, it was evidenced that the work improved the participants' critical sense. In the beginning, they had the impression that evaluating was synonymous with criticizing pejoratively, but throughout the process, they understood the importance of evaluating to improve. According to them, "criticism can build much more than destroy". The most important thing, however, was that the participants began to evaluate themselves, in a very conscious way, when they criticized their own abilities to handle technological resources of information. They found that younger people who needed to work prematurely interrupted their studies before completing them, so they missed the opportunity to enter the information society. In turn, a small number of illiterate participants had difficulty in reading and understanding information. They all acknowledged that they do not take time to engage in the community, although they understood that this was important.

Regarding the analysis of a social problem itself, the researcher showed that the solutions proposed by the participants indicate the development of an active sense of citizenship, even if incipient. Participants were able to identify a social problem in their community, as well as access and use information to analyze this problem. They could also perceive what their new roles would be, guided to either implement or request implementation of projects to solve their local problems. 
The importance of this research was to create a procedure to enable people to handle information critically in an integrated and collaborative manner. From using these participatory techniques, one of the aspects of citizenship development could be verified, which is citizens' involvement with the community, their commitment to the problem solution, and the recognition of their rights and duties.

\subsection{Steps to Make PRA Real}

Theoretical studies on participatory informational literacy point to six participatory processes, which are done in workgroups (TAVARES, 2011; CHAMBERS, 2005). First, citizens select one of the public needs from their community, like a social problem that needs to be solved or a lack of knowledge that needs to be fulfilled. Second, they identify their information needs related to the selected need. Third, they seek information from information repositories. Forth, information is analyzed and criticized for understanding its content. Then, citizens use it to make decisions and solve social problems. Finally, citizens feed information repositories with new information produced during their PRA practice.

To make PRA real is not trivial. In dominated societies, it is essential to make a roll of environmental changes in order to transform the place where people think, reflect and act. It is about a large structural change which would probably be planned and implemented slowly.

From beginning, some steps are described in the sequence. First, public authorities need to define public places inside each local communities, where small groups of citizens can meet. It could work in classrooms, churches or libraries, for example.

Second, it is necessary to build physic and logistic infrastructure, where citizens could have pleasant and comfortable meetings. It means a place with chairs, table, TV, internet, magazines, books, computers, blackboard, paper, pen/pencil, and everything else necessary for meetings.

Later on, a technical facilitator needs to be provided. This person will act only to help people work together, promoting interaction, stimulating discussion and everything else necessary to create an environment of exchange, interaction, consensus and decision-making. Facilitator needs to be an organizer instead of advisor. They would have not any authority or influence on participants discussion or decision. Their role is only restricted in organizing meetings and motivating people to work together, discussing about problems and situations inside their community.

The making-solution process have to work inside communities and with entire citizens participation. Then, facilitator need to invite people for meetings. Thus, they will let citizens get together as much time as citizens want, discussing and getting consensus about actions and solution.

In the end of these processes, a formal document has to be made and driven to public local authorities. This document should have two schedules. The first to convert decisions into projects to be carried out by community members. The last, those projects will drive to public and private sector to search financial resources.

Last, but not least, authorities who decide to adopt these participatory techniques inside local communities need to begin working with a large and general project. It has concerned about structuring critical awareness education for citizens, training platform for facilitators and government publicity for all stakeholders involved. Denotation that everyone will be put together in the same direction, search the same aim, and implement the same project.

People, black or white, poor or rich, men or women, young or elderly, all of them are citizens in their societies. Thus, citizenship development would probably need be claimed by all of them, together, despite of their conditions or singularities. Above others issues, citizens need to defend this common cause, which is emancipation, autonomy and dignity for all. This happens only when citizens start to be conscious about how their society work and what they can do together to solve social problems and make social decisions about issues that affect their lives.

The current cycle of information literacy is defined by several authors in four steps, described as needs' survey, search, access and use of information (DEMO, 2002; CHOO,2006; BELKIN and VICHERY, 1989; BATES, 2002; HEPWORTH and WALTON, 2009, CHAMBERS, 2005 among several others). This article, however, proposes a new cycle in which information accessed goes through filters for understanding, analysis and criticism its content. Only after that, information will be used in order to produce effective and real knowledge for citizens. It means to say, a new cycle would be described in five steps. First, to identify and survey information needs. Second, to search information in information repositories. Third, to access information. Forth, inside social organization of learning, to reed, analyze and criticize information, together, in order to understand its content. Only after that, the fifth step is to use information in order to solve problem and make decision.

\section{Conclusion}

This research has the objective to demonstrate that collaborative work combined with multidirectional and interactive communication in PRA can develop critical awareness and citizenship. Findings points to citizens working together in a 
social organization of learning, where citizens could learn how to search information at reliable information repositories. Additionally, they could access and use the information to understand subjects, share knowledge, discuss situations and make decisions about issues that affect their lives.

It was evidenced that participatory investigation that uses multidirectional and interactive communication can contribute to developing skills related to information literacy and collaborative work, which together promote citizenship development. Participatory intervention research has been a revolutionary methodology in social research for exploring reality in a unique way, giving conditions to both the researcher and the researched to understand reality together, creating synergy and opening new perspectives. This methodology allows participants to work with the researcher, design the project, collect and analyze data and use the results in their own benefits. They stayed together, in small groups, discussing and sharing experiences, suggesting solutions to social situations and problems, showing decision-makers the best course of action to follow.

Conscious citizens, regardless of ideology, would probably analyze information and fake news assertively and manifest against this kind of deceptive attitude, suggesting and demanding severe punishment for public people who act in this wrong way. They would also act against those who manipulate information to confuse people, instigate conflicts and benefit from it.

Finally, critical citizens are smarter and more productive. They make better decisions about their work and their quality of life. They learn better, are efficient and generate more wealth. Conscientious citizens demand more from institutions and the State, but they also make institutions and the State more efficient and effective. In short, critically conscious citizens promote the development of the society where they live in.

Participatory intervention research is a learning tool. It enables people to learn through information literacy and collaborative work, which contributes to the involvement of everyone with the implementation of solutions. It can surely promote changes that will bring benefits for all.

This research did not receive specific cost aid from any public, commercial or non-profitable agency.

\section{References}

Andersson, E., Warburton, D., \& Wilson, R. (2005). The true cost of public participation. INVOLVE - Creation a stronger democracy. Retrieved from www.involving.org

APPLE, M. W. (2008). Can schooling contribute to a more Just society? Journal of Education, Citizenship and Social Justice, 3(3), 239-261. https://doi.org/10.1177/1746197908095134

Argyris, C., \& Schön, D. A. (1996) Organizational Learning II - Theory, Method and Practice. New York: Addison-Wesley Publishing Company.

Bara, F. E. (2021). The conversation. BBC News Brasil. 9/1/2021.

Bates, M. (2002). Toward an integrated model of information seeking and searching. New Review of Information Behavior Research, 3, 1-16. London: Taylor Graham.

Belkin, N., \& Vickery, A. (1989). Interaction in Information Systems: A Review of Research from Document Retrieval to Knowledge-Based System. London: British Library.

Borges, D. (2020-I). Capitalismo e Socialismo, as Duas Faces de Janus: A Fenomenologia do Sujeito de Michel Henry e suas Aproximações com a Crítica do Valor de Robert Kurz. (Capitalism and Socialism, the Two Faces of Janus: Michel Henry's Phenomenology of the Subject and his Approximations with Robert Kurz's Critique of Value). Revista de Filosofia Moderna e Contemporânea, 8(1), 365-400. https://doi.org/10.26512/rfmc.v8i1.28934

Borges, D. (2020-II). A crítica à democracia liberal em Carl Schmitt e Robert Kurz: um estudo comparativo (Criticism of liberal democracy in Carl Schmitt and Robert Kurz: a comparative study). Revista de Filosofia, Amargosa -BA, 20(3), 194-210. https://doi.org/10.31977/grirfi.v20i3.1902

Brookfield, S. (1997). Developing Critical Thinkers. San Francisco: Jossey-Bass.

Calabrese, A., \& Burgelman, J. C. (1999). Introduction. In Communication, Citizenship, and Social Policy: Rethinking the limits of the Welfare State. England: Rowman \& Littlefield Publishers, Inc, 1999.

Chambers, R. (2005). Participatory Workshops - A Sourcebook of 21 Sets of Ideas and Activities (4th ed.). London: Earthscan.

Choo, C. W. (2006). The organization of knowledge: how organizations use information to create meaning, build knowledge, and make decisions (2nd ed.). Translated by Eliana Rocha. Sao Paulo/Brazil: Senac.

Cogo, D., \& Maia, J. (Org.). (2006). Communication for citizenship. Rio de Janeiro: EDUERJ, 2006. 
Cornwall, A. (1996). Toward participatory practice: participatory rural appraisal (PRA). In de Koning, D., Martin, M. (Eds.), Participatory Research in Health. London: Zed Books.

Demo, P. (2002). Introduction to sociology: complexity, interdisciplinarity and social inequality. São Paulo: Atlas, 2002.

Freire, P. (2007). Pedagogy of autonomy: knowledge necessary for educational practice. Special Edition. São Paulo/Brazil: Peace and Earth.

Henten, A. (1999). Will information Societies be welfare societies. In: Communication, Citizenship, and Social Policy: Rethinking the limits of the Welfare State. England: Rowman \& Littlefield Publishers, Inc, 1999.

Hepworth, M., \& Walton, G. (2009). Teaching Information Literacy for Inquiry-Based Learning. Cambridge: Woodhead Publishing. https://doi.org/10.1533/9781780630175

Kurfiss, J. (1997). Critical thinking. Washington, DC: George Washington University Press.

Lloyd, A. (2007). Recasting information literacy as a sociocultural practice: implications for library and information science researchers. Information Research, 12(4). Retrieved from http://InformationR.net/ir/12-4/colis34.html

Mackeracher, D. (2004). Making sense of adult learning (2nd ed.). Toronto: University of Toronto Press Incorporated.

Marshall, T. H. (1964). Class, Citizenship and social development: Essays. Garden City, New York: Doubleday, 1964.

Rinaldi, R. (2019). Ready writing: The dangers of Fake News in the Information Age.blog.imaginie.com.br, 3/26/2019.

Tavares, R. B. (2011). The use of participatory research techniques in the communication of information in communities, taking into account informational literacy and collaborative work for citizenship development. Doctoral thesis University of Brasília, Faculty of Information Science, Graduate Program in Information Science, Orientation: Sely Maria de Souza Costa.

\section{Copyrights}

Copyright for this article is retained by the author(s), with first publication rights granted to the journal.

This is an open-access article distributed under the terms and conditions of the Creative Commons Attribution license which permits unrestricted use, distribution, and reproduction in any medium, provided the original work is properly cited. 